Article

\title{
A Countryside to Sip: Venice Inland and the Prosecco's Uneasy Relationship with Wine Tourism and Rural Exploitation
}

\author{
Francesco Visentin * (D) and Francesco Vallerani ${ }^{(D)}$ \\ Department of Economics, Ca' Foscari University of Venice, Cannareggio 873, 30121 Venezia, Italy; \\ ramusa@unive.it \\ * Correspondence: francesco.visentin@unive.it
}

Received: 12 May 2018; Accepted: 15 June 2018; Published: 27 June 2018

\begin{abstract}
In 2016, Italian production of wine exceeded 51 million hectolitres and among the twenty regions, the region with the most production by volume (millions of hectolitres) was the Veneto region, north-east of Italy, with almost 11 million. In particular, the success of Prosecco at the global level is the most important driving factor at both the economic and productivity levels. The worldwide success of Prosecco wine entails a remarkable change in both the local and regional configuration of agrarian landscapes. Traditional winegrowing swiftly changed into an intensive monoculture with remarkable investments and the spread of new viticulture entrepreneurships. The discussion proposed here intends to investigate the process of heritage construction or 'heritagisation', UNESCO candidacy, as an important issue for rural tourism promotion in the context of a productive winescape. We concentrated our analysis on the DOCG area, a complex space where several forces need to coexist; the productive drive of growing requests (global and local) of Prosecco, as well as rural representation based on local habits and a concrete hilly landscape. Rural tourism is clearly an important sector in terms of revenue and employment, especially for local communities, and it can help to ensure economic stability; however, doing so in a way that benefits the area and the landscape is not so straightforward. There are potential problems in facilitating increased urbanization, such as the standardization of landscape and damage to the area if plans are mismanaged. In the case of best practices, a desirable model of tourism can be tapped into while helping rural regions take advantage of more sustainable tourism development and landscape management.
\end{abstract}

Keywords: rural tourism; Prosecco; heritagisation; landscape management; sustainable activities

\section{Introduction: The 'Prosecco Turn' and Its Cultural Landscapes}

The primary goal of this paper is to develop a qualitative analysis of the conflicting landscape evolution of the Prosecco hills located in the Veneto region of Italy, according to the cultural geography approach where heritage and landscape are viewed as the embodiment of cultural influences on nature. Both of them are windows through which cultures can be studied and understood [1]. Common narratives about sustainability are usually founded on the interaction between social attitudes and economic needs. The idea of 'rural' is grounded on the expansion of urban polarities well beyond the traditional organic pertinences of the city, thereby giving a powerful new relevance to the traditional vocations of the countryside [2]. It follows that the usual opposition between city and countryside continues, to an increasing extent, show its limits, especially in the light of the growing complexity and fast evolution of the dynamics that all social groups and corresponding territorial areas to interact and mix. Today in fact, rural settlements accommodate a growing number of residents of urban origin and medium-high levels of education and income. These people continue to work in the city and maintain 
a more or less urban lifestyle while commuting daily. This situation is easily detectable in manifold rural sections of the Venice inland. The case study of the Prosecco area offers a great deal of intriguing ways to interpret this growing complexity of the traditional antinomy of urban versus rural with the additional expansion of social hybridity where different existential visions collide. Urban sprawl, social conflicts and environmental degradation are the most noticeable key words used to define a peculiar territoriality whose interpretation needs a definitely interdisciplinary approach.

The production of Prosecco wine can be identified with a specific section of the central Venetian countryside, roughly corresponding to the rolling slopes between the Piave and Meschio rivers. This hilly morphology lies at the southern margin of Prealps, and it is the first relief seen when coming from the flat extension of the Padana plain. Despite the low altitudes, the vertical profile of this hummocky range is definitely undulating, with steep slopes and a thick succession of narrow dales that sometimes take the form of dramatic ravines where sediment strata are more resistant. As to the geology of this hill country, the structure is made up of materials which originated during the Miocene period. Such materials are not homogeneous; clays and loose sandstones mix with conglomerates and isolated layers of limestone. Due to the erosion process, complex physical features and the centuries-old well-established human presence gradually transformed the territory into a unique rural landscape where winegrowing is the primary activity and economic base.

In 2016, the Italian production of wine was more than 51 million hectolitres and among the twenty regions, the top for production by volume (millions of hectolitres) was the Veneto region with almost 11 million. In particular, the success of Prosecco at the global level is the most important driving factor at both the economic and productive levels. Prosecco became a proud 'territory' that never passes up the occasion of flaunting having sold more bottles (307 million) globally in 2013 than Champagne (304 million), according to the Italian Sparkling Wine Observatory [3]. The area of the Prosecco DOCG (Denominazione di Orgine Controllata e Garantita, more restricted quality guarantee), is located on the slopes of the Pre-Alps and overlooking a bend of the Piave River in the northeast of the Veneto region, 20 miles from Treviso. It is exactly between of a north-south imaginary line joining two famous UNESCO sites: Venice (and its lagoon) and the Dolomites (Figure 1).

In this geographic and cultural context, it is necessary to clearly define the space of production of Prosecco because with a decree dated 17 July 2009, the entire hills area assumed the status of DOCG replacing its previous classification as a DOC (Denominazione di Orgine Controllata, controlled origin denomination), which had been in place since 1969. The same decree extended the area of the DOC to nine provinces in northeast Italy (in two regions: Veneto and Friuli Venezia Giulia) previously identified as Prosecco IGT (Identificazione Geografica Tipica, labeled with the locality of their creation) [4] (It is important also to distinguish the wine, Prosecco, from the grape variety, Glera. As highlighted by Tomasi, Gaiotti and Jones, ' . . . the decree of 22 April 2011 sanctioned the substitution for Prosecco variety of the name Glera, which was already listed in the National Register of Grape Varieties as historical synonym of Prosecco. This move thus intended to avoid superimposing the name of wine on its grape variety [ ... ]. Prosecco is no longer the wine obtained from a grape variety but has become the wine of a specific growing area' (2013: 11).). This change allowed the transfer of the name of the variety of wine to an area, so now the name of Prosecco identifies both a DOC/DOCG wine and two growing areas, contributing to the 'Prosecco Turn'. With this concept, we would like to stress a broad interest in Prosecco in many fields; from society to scholars who contributed (consciously or not) to posing Prosecco at the centre of many discussions and analysis from the economic point of view to Prosecco's heritage; from the tourism perspective to the sustainability of environment; and from the historical landscape to its current rural commodification. In Italy, grape growing has created a huge diversity in the rural landscapes and the production of a multiplicity of wines that differ in terroir, sensorial characteristics, and historic and cultural aspects. The role played by viticulture, in addition to the production of wine, particularly quality wine, is essential for the preservation of the different and well-known landscapes. 


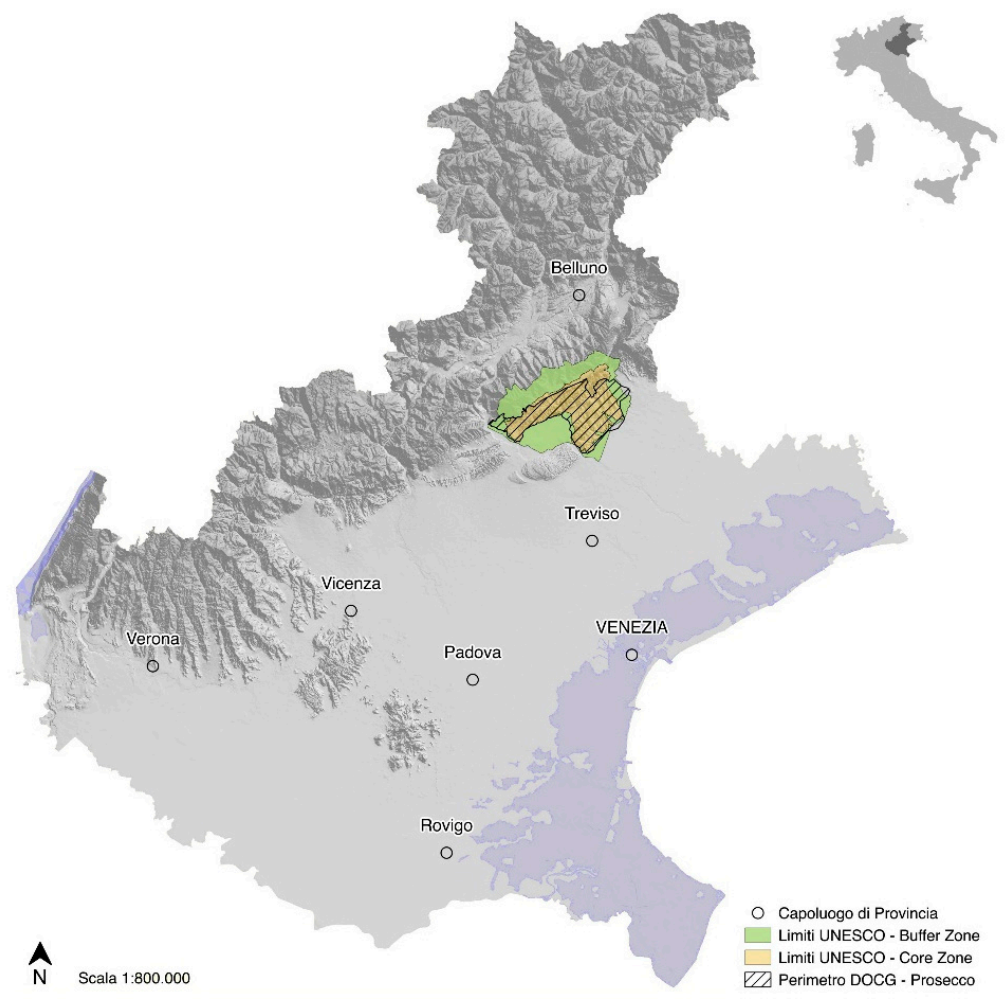

Figure 1. The map of Veneto Region, in the north-east of Italy: the area of the Prosecco DOCG at the southern margin of Prealps not so far from Treviso and Venice (Elaborated by Antonio Visentin \& Francesco Visentin).

One of the most famous and recognized of these landscapes is the vineyards of Langhe-Roero and Monferrato in the Piemonte region inscribed in the UNESCO World Heritage list in 2014 because ' ... the names evoke profound and ancient expertise in the relationship between man and his environment. They reflect a slowly developed association between a diverse range of soils, grape varieties that are often native, and suitable winemaking processes' [5]. Following this successful initiative, in 2009 the candidacy of 'The Prosecco Hills of Conegliano and Valdobbiadene' was launched to become a UNESCO World Heritage Site, and in 2010 a proposal was submitted to the tentative list in the category of 'Cultural Landscape'. According to the dossier, 'The area represents an outstanding cultural landscape of great beauty, containing historic towns and villages, and cultivated lands formed by many centuries of interaction between their population and the physical environment' [6]. In the candidature report, the space of production and the space of 'heritageisation' correspond (with tiny differences); indeed, the boundaries of the productive area as DOCG correspond to the boundaries (core zone) identified by the proponents of candidacy for the cultural landscape area (Figure 2).

This process of 'heritageisation' poses some questions concerning the definition of territorial identity, as heritage remains a complex field of inquiry [7]. The discussion proposed here intends to investigate the process of heritage construction or 'heritagisation' as an important issue for rural tourism promotion in the context of a productive winescape. We concentrated our analysis on the DOCG area, a complex space where the at same time the productive drive of growing requests (global and local) of Prosecco must coexist with rural representation based on local habits and a concrete hilly landscape that is more than a result of human activity; it is both a material thing and a conceptual framing of the 'rural' world (The Conegliano-Valdobbiadene DOCG area includes 15 municipalities: Valdobbiadene, Conegliano, Cison di Valmarino, Colle Umberto, Farra di Soligo, Follina, Miane, Pieve di Soligo, Refrontolo, San Pietro in Feletto, San Vendemmiano, Susegana, Tarzo, Vidor, Vittorio Veneto). Rural tourism is clearly an important sector in terms of revenue 
and employment, especially for local communities, and it can help to ensure economic stability; however, doing so in a way that benefits the area and the landscape is not so straightforward. There are potential problems in facilitating increased urbanization, which could lead to standardization of the landscape and damage to the area if plans are mismanaged. In the case of best practices, a desirable model of tourism can be tapped into while helping rural regions take advantage of more sustainable tourism development and landscape management.

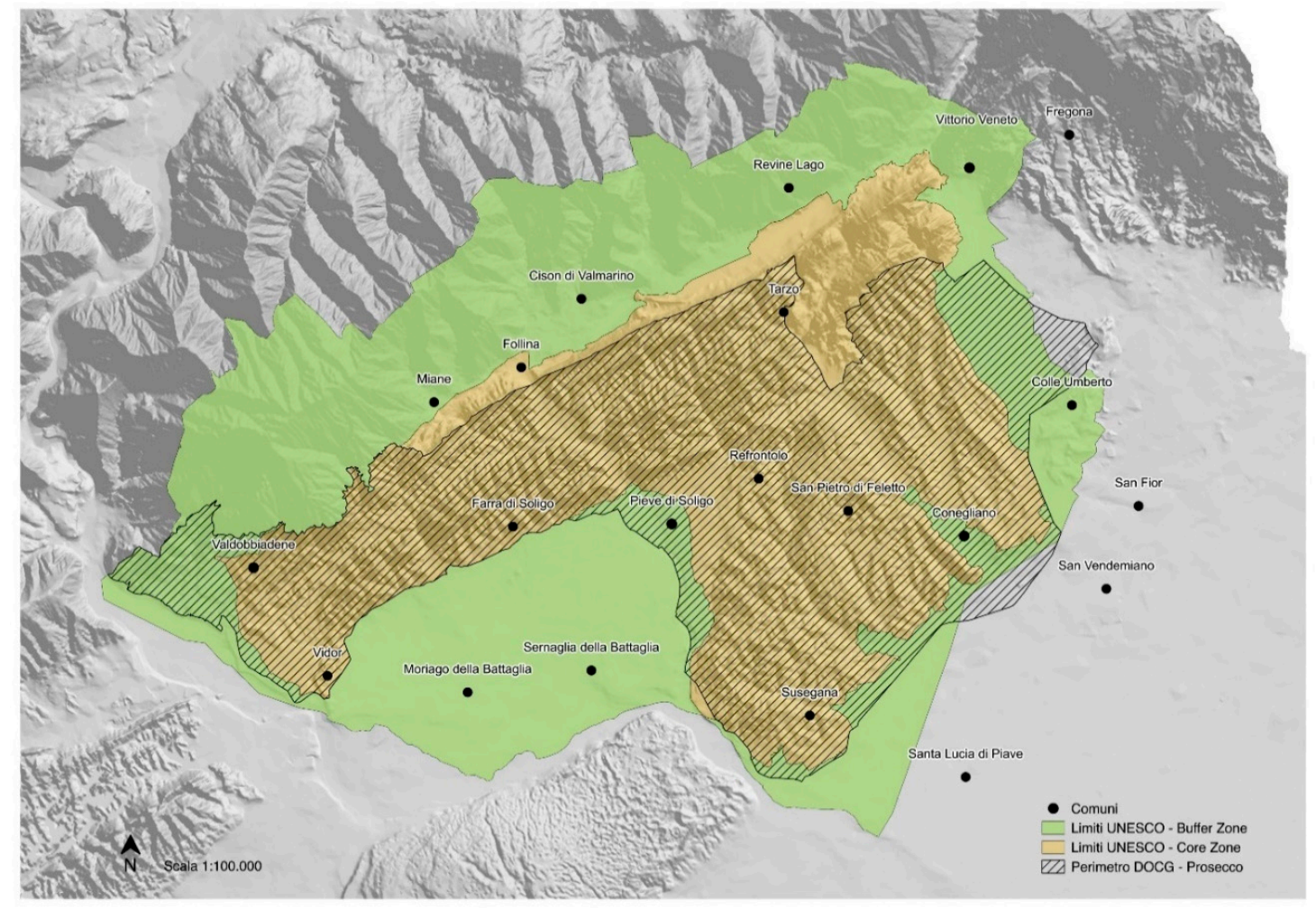

Figure 2. The boundaries of the productive area as DOCG corresponds to the boundaries (core zone) (Elaborated by Antonio Visentin \& Francesco Visentin).

\section{The Venice Inland: From Traditional Agriculture to Urban Sprawl}

Not unlike other analogous landscapes in the Veneto region, and well before the present-day global boom of Prosecco popularity, this area attracted the Venetian aristocracy. The spread of urban interests in the countryside is not only the result of the well-documented dwindling of Venice as the imperial city set up maritime trades, but also a specific affirmation of cultural attitudes fuelled by the coeval recovery of Arcadian ideals [8]. It follows that since the beginning of the sixteenth century, there have been a great many prestigious villas spread all over the Venice inland, with a notable concentration in hilly areas. Rural settlements were mostly tiny villages positioned at the foot of the first row of pyramidal hills or in the largest valleys separating the succession of parallel relief rows northward. Their structure was a dense agglomeration of small farms mainly devoted to winegrowing and dairy cattle (Figure 3). Up until the second half of the last century, these activities provided such low incomes that a noteworthy section of local population was forced to migrate abroad (mainly to Switzerland and Germany). The main centres of this sub-regional area are the small towns of Valdobbiadene and Conegliano.

Before the recent collapse of traditional agriculture, the names of Valdobbiadene and Conegliano were strictly related to the production of Prosecco. Their geographical position actually encompasses the hilly landscapes that at present overlap the core zone included in the above mentioned tentative UNESCO World Heritage Site list. 
The name Prosecco comes from a village located not far from Trieste, in the narrow plateau between the karstic relieves along the Italian-Slovenian border and the abrupt slopes dominating the Adriatic Sea. Thanks to toponymy research, it became clear that the name Prosecco corresponded to the Italianisation of the Slovenian word prosek, which means 'deforested area' [9]. Since the end of sixteenth century, the cultivation of local grapes in both the plateau and terraces surrounding the Prosecco village had to be distinguished for commercial purposes. Ribolla was the prevailing name of the grapes in Karst area stretching from Trieste to eastern Friuli. Due to the higher quality of the Ribolla wine produced in the specific area close to Prosecco, local authorities decided to change the name of this very local wine to Prosecco [9] (pp. 25-28). In the second half of the nineteenth century, further initiatives arose concerning the technical amelioration of grapes and vineyards in the hilly landscapes between Valdobbiadene and Conegliano. The establishment of the Treviso Oenological Society in 1868 in Conegliano, which a few years later (1876), changed its tasks and goals and became the School of Oenology and Viticulture, had a major role in fostering both grape growing and winemaking $[10,11]$. Very soon, this school gained the nationally accredited recognition that allowed for the spread of the Prosecco in regional markets [12]. This leading role was enhanced after the end of World War I when ravaging diseases caused by the spread of phylloxera and downy mildew affected large sections of Italian vineyards [13]. Thanks to the researchers working in the school's laboratories, effective innovations were achieved to control and contain the propagation of these plagues. It follows that in 1923, a new Experimental Centre for Viticulture and Oenology (Stazione Sperimentale di Viticoltura e Enologia) was set up within the school in Conegliano [14].

As to the knowledge of the agrarian landscape features where the Prosecco vineyards are localised, we can rely on the technical report set up by Angelo Vianello and Antonio Carpenè in 1873. Thanks to their detailed accounts, the territorial structure shows a fragmented distribution of small farms where the polyculture framework prevails. This is a situation of small-scale production aiming at the achievement of food self-sufficiency within precarious familiar livelihoods [15]. Further information on the traditional agriculture throughout the undulate landscapes considered here comes from the 1880 Agrarian Census (Inchiesta Agraria) conducted by the Italian Kingdom. This helpful source confirms the secondary role of viticulture. It actually coexists with the cultivation of chestnuts and the breeding of scarce livestock to obtain milk and wool to satisfy the needs of poor families [16]. The backwardness of local farmers persisted until the 1960s, which may account for the unintentional conservation of the high visual quality of traditional agrarian landscapes.

Veneto's dense urban network, from the Alpine foothills to the coast, has accommodated a fractured and scattered production model devoid of any elementary planning structure, which has favoured the almost automatic switch from small farming properties to an initial stage of artisan entrepreneurship that marked the start of the by now famous 'Veneto model' beginning in the second half of the twentieth century [17]. Due to the economic boom of the period in Veneto's mainland, an astonishing urban dispersion abruptly began to change the traditional landscape's patterns (Figure 4). The prestigious features of the distinguishing Palladian landscape have been involved in a prolonged and devastating erosion of the main elements making up the backdrop against which the masterpieces of the Veneto architecture are set [17]. But the built-up countryside is also the result of agronomic transformation following the fast and huge drop in the number of farm workers, the spread of new production processes, new distribution rules and crop management methods. The prevalence of monocultures caused a simplification of traditional physiognomic orders and an ecological degradation of hydrography and soils. Agribusiness required the removal of trees and hedges, the covering of most ditches, the abandonment of many rural buildings and, in short, a general disaffection for the not-directly productive aspects of the landscape. To some extent this is a recent evolution affecting the traditional features of the Prosecco landscape, even though the expanding importance of both wine and rural tourism is imposing a more careful management of aesthetic elements and cultural heritage among the hilly vineyards. 


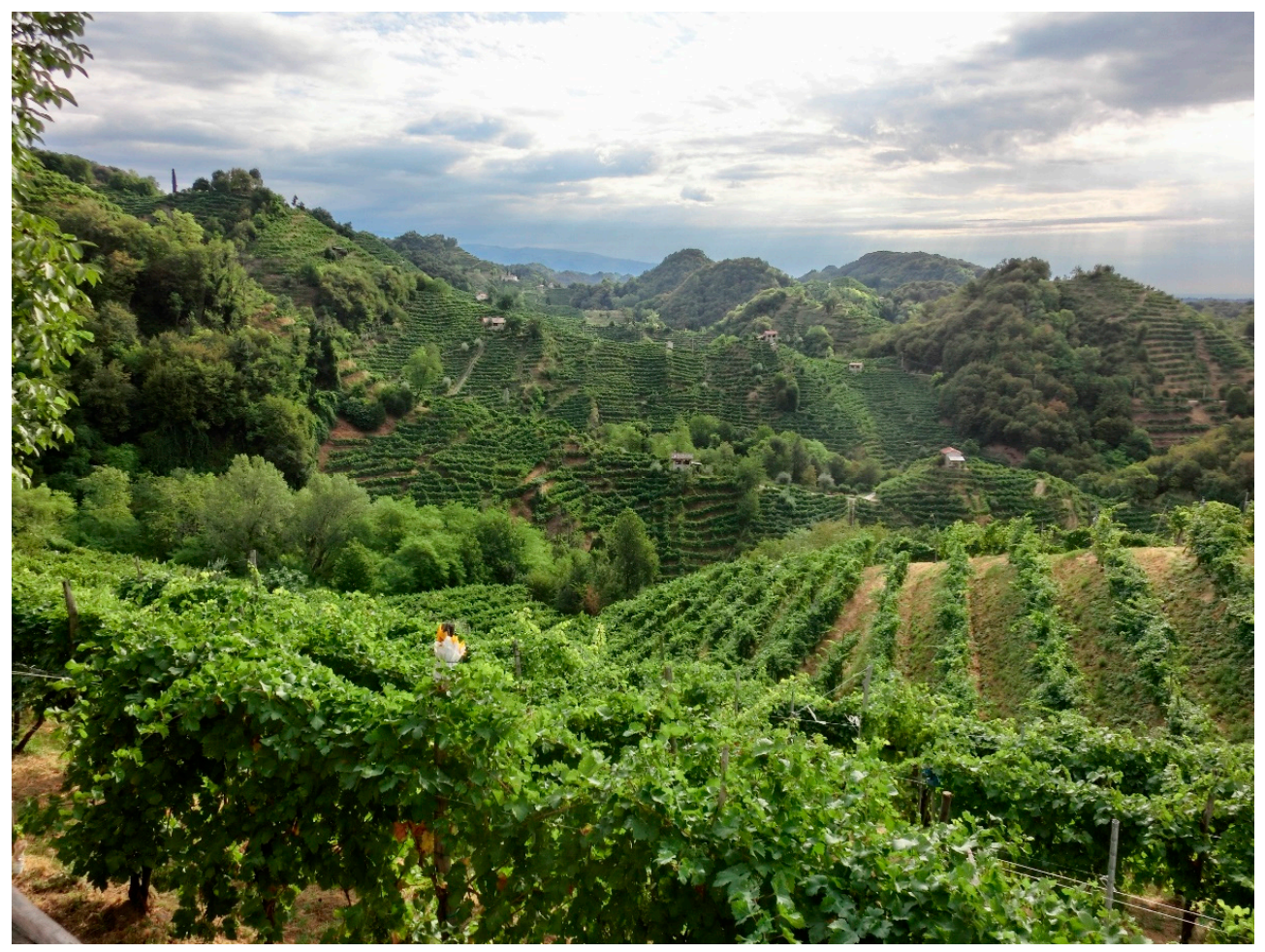

Figure 3. A view of morphological complexity of the reliefs with the different visual elements harmoniously arranged within a scenery of undisputable attractiveness. It is worth noting the remarkable presence of mesothermal woods, mostly covering the steepest slopes and the top sector of the hilly ranges. (Photo by F. Vallerani).

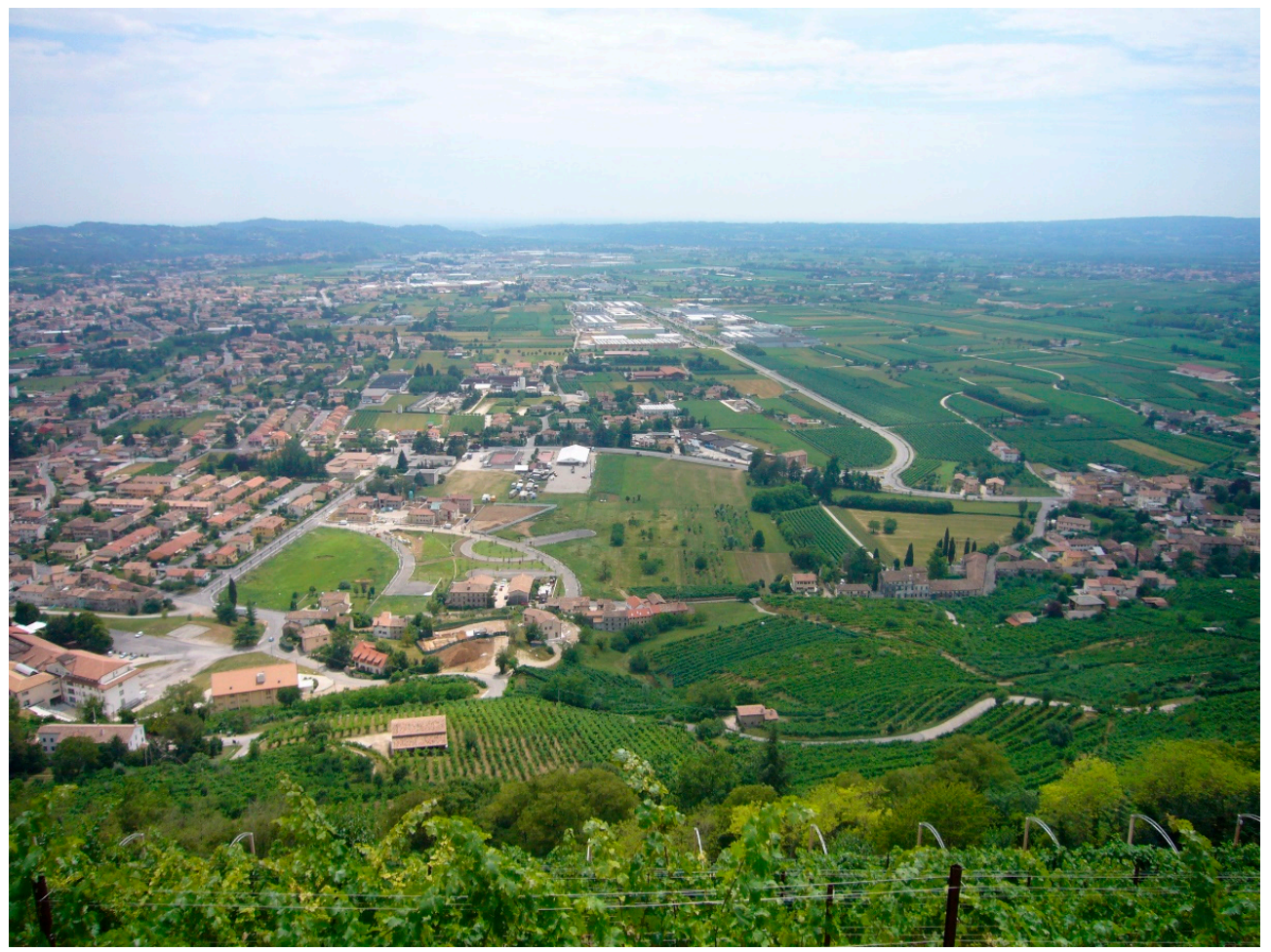

Figure 4. A view from the San Gallo's hill on the urban sprawl between the small towns of Farra and Pieve di Soligo. (Photo by F. Vallerani). 


\section{Exploiting Rural and Wine Tourism}

\subsection{Discussing (Rural) Tourism}

More than $50 \%$ of world tourists travel to Europe, and Italy is one of the leading global and European tourism destinations [18]. In the Belpaese (as Dante appealed Italy), the arrivals increased by $5.4 \%$ in 2017 [19] with a total amount of over 117 million arrivals [20,21]. As for Italian tourism, Veneto is the most visited region of the peninsula with a tourist flow of $69,184,082$ for 'overnight stays' and 19,172,576 arrivals in the 2017 period [22] (According to the UNWTO's Compendium of Tourism Statistics, the data related to inbound tourism are divided into total arrivals and overnight stays [23]. Inbound tourism is comprised of the activities of non-resident visitors within a country during an inbound tourism trip. These visitors' corresponding expenditures are identified as inbound tourism expenditures. Arrivals $=$ the total amount of visitors. Overnight stays $=$ the number of nights a tourist stays in hospitality structures. The relationship between these two categories allows us to calculate the average number of nights a tourist stays). Venice has the lion's share of tourists, but thanks to the geomorphology of the region and to its various and diffused historical heritage sites, the tourist destinations in Veneto are classified by the Tourism Department of Veneto into six categories: Mountains, lakes, seaside, historical cities, thermal and hills/territorial/cultural. In this variegate context of different types of tourist attractions, eco-gastronomic tourism represents a more 'elite' tourist profile with a high level of per capita daily expenditure [24,25]. Food and wine tourism are often associated with several forms of ecotourism and responsible tourism, as attested by the growing trends of social responsibility in the tourism industry [26,27]. The growing of slow and sustainable tourism (including food and wine tasting) is confirmed by one of the last tourism seasonal reports of the Veneto region in October 2015, which affirmed the relevance of slow and food tourism-with a specific reference to the wine-for the tourism economy of the region, especially during the last economic crisis [28].

If wine is one of the major sectors in eco-gastronomic tourism today in Italy [29], wine and food tourism moved into the mainstream in the peninsula in the 1990s thanks to the Wine Tourism Movement that managed to persuade a number of Tuscan wineries to create an open-door initiative called 'Cantine Aperte' (Open Cellars, first edition, 1993). From this first attempt, the number of viticulturists grew from the initial 25 wineries to the 21,000 that participate today in opening their doors to the public; visitors grew in numbers from a couple of hundred 20 years ago to the current 4 to 6 million, and in 1999, a legislation regulated the Italian 'Wine Routes' [30] (The Wine Routes in Veneto Region were recognised and established in September 2000. At the moment there are 19 routes. For more information: https://www.regione.veneto.it/web/agricoltura-e-foreste/turismoenogastronomico).

Indeed, many of the country's rural regions are popular with tourists. Hence, wine tourism is considered to fit perfectly with Italy's rural regions. Moreover, the Italian wine routes are seen as a means of linking agro-food production to a new and differentiated development of rural spaces. Furthermore, wine is ranked third on the motivation lists of foreign tourists visiting Italy. Almost 3.5 million tourists visit the country's wineries per year. Also, through scholars [30-34], wine tourism has received considerable attention with a growing body of research into the complementarity of food and wine tourism [35-37].

Tourism in agricultural regions is not limited to visiting sites that have a specific agricultural character; it may also include natural and (sub)urban areas. The relationship between landscape and tourism has received considerable attention in academic literature [38]. From a landscape perspective, Terkenli [39] described the relationship between tourism and landscape as inextricable, while other research has classified this relationship as a particular attribute of the cultural landscape [40], which has also been referred to as the 'tourism landscape' [41]. From a tourism perspective, a number of authors have commented on the importance of landscapes as a factor that attracts tourists to rural (including agricultural) areas [42-45]. The role of landscape in establishing place identity has also been a focus of research in both landscape and tourism literature. Many governments and regional authorities 
have embraced rural tourism as an opportunity to bring new money into rural regions, stimulating growth, providing employment opportunities and thus beginning to halt rural decline [46-50].

The decline of traditional economic activity, the restructuring of the agricultural sector, rural industrialisation and the out-migration of higher-educated youth has led to the adoption, in many Western nations, of 'tourism and leisure' as an alternative development strategy for the economic and social regeneration of rural areas [50]. Scholars have suggested a number of definitions and typologies for rural tourism to explain the growing demand for organic and authentic products (related to Western countries) and why this is attracting both new dwellers and second-home owners to expanding sections of the abandoned countryside. Difficulties in defining rural tourism have led to difficulties in measuring its impact at local, regional, national and international levels.

Rural tourism is not necessarily located in an intensely productive countryside but in specific landscapes showing features that are functionally rural [43,48]. This kind of tourism or leisure activity finds its roots in rural landscapes where local cultures are still affecting everyday lifestyles. The predominant use of rural space for leisure and recreation by a large part of urban people has transformed public perceptions of the rural, in the western countries, challenging the political primacy of agriculture. The possibilities of rural tourism to promote rural regeneration have been criticised for being overstated and sometimes unrealistic. Miller, Van Megen and Buys [51] (p. 10) argue that rural tourism is not 'a magic panacea' for overcoming the complex and deep-rooted problems facing rural regions around the world; however, it may provide one avenue, amongst others, for rural growth and (re)development. The countryside and the rural landscape run the risk to be modified, transformed and conformed to meet tourist expectations and the increasing number of tourists can also have an impact on congestion and pollution.

\subsection{What about the Prosecco?}

Regarding the Prosecco DOCG area, the importance of the beauty of landscape in the perception of wine quality has been investigated by various authors [52-54]. Several researches have also examined the development of rural tourism in Conegliano-Valdobbiadene from the ecological perspective, focusing on the role of the Prosecco DOCG as a factor in the attractiveness of the area [55-57].

In the case of the Prosecco DOCG area, we can observe a constant growth of both the bottles produced and the revenues from sales, which grew from the 70 million bottles in 2013 (362.2 mil. $€$ ) to 90 million in 2016 (492.5 mil. $€$ ). This increase in production has had a direct impact on the landscape. Indeed, there has been a remarkable expansion in the area of production; the number of hectares dedicated to the winery of Prosecco in 2013 was 6578, in 2014 it was 6861, the year before 7195, and in 2016, it was 7549 hectares. In just four years, 1000 hectares more were converted to productive vineyards (Distretto Del Consorzio Conegliano-Valdobbiadene: Rapporto Annuale, [58-61]).

At the same time, the relevant growth of production and the productive area coincides with a similar expansion of tourists and visitors, although we must highlight some particularities. In a recent report elaborated by CISET (International Centre of Studies on the Tourism Economy) from 2015 to 2016, arrivals in the DOCG grew 6.4\% and overnight stays grew 12.5\% [57], and more generally, since 2007, a constant growth in the arrivals was registered ( $2 \%$ per year) while for with overnight stays, the numbers are more or less the same, but we have to consider the general decrease of permanence in the tourism sector in Veneto (from 2.7 per night in 2007 to 2.2 in 2016) and take into account the economic crisis that affected, in particular, the internal market between the 2010 and 2014 (Table 1).

In particular, if we focus on the total number of foreign visitors, the total amount has grown from $38.3 \%$ (arrivals) and 39.4\% (overnight stays) in 2007 to the $43.1 \%$ and $46.7 \%$, respectively, in 2016 . This growth is probably due to the large success of the Prosecco wine in the global market (According to the reports realized by the "Centro Studi del Distretto Conegliano-Valdobbiadene DOCG" the Prosecco was exported in 2013 to more than 80 countries (40.4\% of total production) and in 2016 to 130 countries $(42.04 \%)$ ). If we take into account a more in-depth analysis of wine visitors at the cellars conducted by CIRVE (Inter-department Centre of Viticulture and Oenological Research), and not of tourists in 
general, the flow registered in the area has grown considerably, from 151,000 in 2008 to 337,000 in 2016 [62], a growth rate of $83 \%$. Of those, 35\% visited the Veneto region, some of whom could be considered as day-trippers especially interested in buying wine directly in the cellars rather than simply tourists tout court.

Table 1. Arrivals and overnight stays in the Conegliano-Valdobbiadene DOCG area, 2007-2016 (elaborated by CISET). This table is about tourists in general, not just the wine tourists.

\begin{tabular}{|c|c|c|c|c|c|c|c|c|}
\hline \multirow[b]{2}{*}{ Year } & \multicolumn{2}{|r|}{ Italians } & \multicolumn{2}{|r|}{ Foreign } & \multicolumn{2}{|c|}{ Total Amount } & \multicolumn{2}{|c|}{ Var. $\%$ on the Previous Year } \\
\hline & Arrivals & Overnight Stays & Arrivals & Overnight Stays & Arrivals & Overnight Stays & Arrivals & Overnight Stays \\
\hline 2007 & 67.939 & 181.878 & 42.244 & 118.402 & 110.183 & 300.280 & $+6.4 \%$ & $-0.6 \%$ \\
\hline 2008 & 68.616 & 170.488 & 43.356 & 109.037 & 111.972 & 279.525 & $+1.6 \%$ & $-6.9 \%$ \\
\hline 2009 & 61.730 & 134.676 & 36.423 & 90.586 & 98.153 & 225.262 & $-12.3 \%$ & $-19.4 \%$ \\
\hline 2010 & 72.245 & 160.867 & 40.256 & 103.358 & 112.501 & 264.225 & $+14.6 \%$ & $+17.3 \%$ \\
\hline 2011 & 69.339 & 164.127 & 41.427 & 116.953 & 110.766 & 281.080 & $-1.5 \%$ & $+6.4 \%$ \\
\hline 2012 & 64.811 & 145.019 & 42.854 & 110.381 & 107.665 & 255.400 & $-2.8 \%$ & $-9.1 \%$ \\
\hline 2013 & 64.395 & 135.590 & 43.995 & 109.634 & 108.390 & 245.224 & $+0.7 \%$ & $-4.0 \%$ \\
\hline 2014 & 69.374 & 141.146 & 48.157 & 116.265 & 117.531 & 257.411 & $+8.4 \%$ & $+5.0 \%$ \\
\hline 2015 & 73.306 & 141.349 & 53.586 & 124.463 & 126.892 & 265.812 & $+8.0 \%$ & $+3.3 \%$ \\
\hline 2016 & 76.782 & 159.409 & 58.244 & 139.730 & 135.026 & 299.139 & $+6.4 \%$ & $+12.5 \%$ \\
\hline
\end{tabular}

These exceptional numbers have also to be read from two perspectives with respect to the development of rural-wine-tourism. From one side, the strong connection between the wine and the production area-well demonstrated by the relevant percentage $(76 \%)$ of cellars that are also vineyards (farms)—show a quite important feature for the wine market because wine is perceived as typical, and it does not derive these perceptions only from the DOCG labelling that indicates the area of production and relevant regulation [56]. From the other side, some data regarding accommodation capacity reflects a certain lack of preparation for the sector with respect to, for example, the possibility of staying overnight (only $12 \%$ of the cellars are able to host their visitors for the night) in the winery or being able to satisfy visitors through a catering service $(7 \%)$. This is probably due to the high numbers of diffused structures in the area that are involved in the 'hospitality industry'. Before the development of wine tourism, the area was a common destination for local visitors and cultural tourists who were interested in its cultural heritage and beautiful foothills. With increasing interest in Prosecco in recent years, we have seen a significant increase in the number of accommodations (seen in Table 2). There are slight differences between the 2007 and 2017 data. For hotels and B\&Bs, the supply is stable, but there has been growth in agritourism and in the number of guesthouses.

Table 2. Facilities in the area Conegliano-Valdobbiadene, 2007-2017 (From: Veneto Region, Statistics Sector, based on ISTAT data).

\begin{tabular}{ccc}
\hline Facilities & $\mathbf{2 0 0 7}$ & $\mathbf{2 0 1 7}$ \\
\hline Hotels & 37 & 36 \\
Extra-hotel facilities divided into: & 205 & 341 \\
Guesthouse and Flat & 76 & 194 \\
Agritourism & 45 & 61 \\
B\&B & 78 & 79 \\
Camping & 1 & 1 \\
Other & 5 & 6 \\
Total & 242 & 377 \\
\hline
\end{tabular}

In this context, the UNESCO candidacy could represent an instrument for tourism development and for a more controlled and sustainable wine production engagement of all the viticulturists. From the other side, the tourism-World Heritage relationship is now a considerable field of study handled variously between poles where tourism is accorded a role either as a disruptive phenomenon or the designation is seen as a conflictual process that takes place because the community, stakeholders and policy makers do not consider the inscription as a procedure made of 'before, during and after', 
only taking into consideration the site per se and not the wider socio-cultural context in which it operates [63].

\section{Environmental Impacts and the Growing Quest for Sustainability}

The worldwide success of Prosecco wine entails a remarkable change in both local and regional configuration of agrarian landscapes. Traditional winegrowing swiftly changed into an intensive monoculture with remarkable investments and the spread of a new type of viticulture entrepreneurship. This success required the intensification of production, enhancing the exploitation of agrarian environments. The recent increase of urban sprawl and Prosecco monocultures are two akin aspects that shed light on the inadequate regional policies in managing environmental impacts [64].

The dilatation of vineyards is harshly affecting the delightful uniqueness of the undulating rows of hills stretching from Valdobbiadene to Conegliano; in some cases, it is causing serious changes in the natural gradient of the slopes to make room for new vine plantations and mechanical grape harvesting [65]. Further consequences involve the reduction of the remaining original woodlands. Local newspapers are very careful in accounting for continuous deforestation in the core zone of the proposed UNESCO World Heritage Site [66]. Strong reactions among non-farming inhabitants have been rising since the beginning of the Prosecco boom. As quoted in Camilla De Nardi's fieldwork, people like Gianluigi Salvador, the head of the local WWF section, are devoting a great part of their existence to dealing with the risks from intensive winegrowing: 'In the past vines were planted in respect of the environment', said Gianluigi Salvador. 'Today every metre of agricultural surface is deforested and exploited. Cement and big plastic tubes have been implanted using scrapers and other heavy machineries, which can shape the soil anyhow' [67] (p. 17). Such massive dilatation of monoculture in the Prosecco area gained a deplorable reputation at the national level, to the extent that scholars and policy makers in Tuscany aiming at a good territorial management of Chianti and Brunello viticulture quoted the huge expansion of Prosecco vineyards as a bad practice that contributes to the spread of chemical pollutants, besides causing soil erosion and landslides [68].

It is worth noting that such environmental conflict is due to the opposition between people involved in the viticulture (who are not necessarily rooted local farmers, but in some cases outside investors) and non-farming residents. As to the latter, investigating their personal stories was quite interesting. We can actually consider again the notion of rural idyll as the indisputable pulling factor in the process of conceptualizing and experiencing the countryside, where the residential satisfaction and environment enjoyment is more a mythical expectation than an actual condition. Villages in the Prosecco area are in fact a good example of a geographical destination for amenity migrants, whose main prospected goal is a new lifestyle imbedded in a rural context, providing the enjoyment of harmonious landscapes, fresh and unpolluted air, woods and close opportunities for outdoor pursuits [69]. When this pastoral vision changes, as in the case of the 2012 clearing of about 40 hectares of forested hillsides in northwest Conegliano to allow the plantation of new Prosecco vineyards, a shared uneasiness affected a large portion of both locals and outsiders: 'We are sad because these fairy-tale places are disappearing, we are sorrowful and we want to share our sufferance for the loss of these area and their magic landscapes. We have to prevent it to happen again' [70].

The use of rural areas as tourism destinations, especially when successful productions are spreading over larger and larger sections of the landscape tourists would like access to, creates enough room for environmental conflicts. Indeed, Prosecco winegrowing doubtless makes redundant any further economic strategy to develop these rolling slopes. Prosecco monoculture 'is a natural outgrowth of an industrial approach to agriculture, where technology-based inputs are maximized in order to increase productive efficiency' [71] (p. 4), and widespread use of pesticides and herbicides is a common practice within the charming green hillsides where the vines grow. In monoculture winegrowing there is actually a remarkable loss of biodiversity that makes the vines more vulnerable as to the insurgence of phytopathologies. This is the dark side of one of the most fascinating rural landscapes on the planet whose long-established reputation is further strengthened by the expanding success of the Prosecco. 
Due to such a growing demand, the large-scale use of chemical insecticides and herbicides is the conventional strategy to fight the risk of pest and weed invasion.

In the last decade a more and more serious environmental conflict has affected social relationships in the area, fostering the aggregation of a growing number of local individuals into active grassroots movements. Local and regional administrators have been constantly forced to face the increasing amount of information collected by independent researchers concerning the widespread contamination of soils, underground water, non-target organisms and aquatic ecosystems [72]. The wine business completely changed environmental perceptions among local communities and, to some extent, that of tourists. The increasing affirmation of a shared awareness is clearly witnessed by the activities of investigative journalists. Despite the 2009 European Directive on Sustainable Use of Pesticides [73], what mostly raises the concerns of local communities is the scarce attention paid by farmers involved in the frequent phytosanitary treatments. They actually should respect a well-detailed protocol that prohibits spraying during spring flowering or too close to private gardens and backyards. At the end of 2017, four winegrowers sued the Mayor of Pieve di Soligo for stricter control of farmers' activities within urban areas; it is a conflict between the safeguard of citizens' health and the economic interests related to possessing no more than two thousand square meters of soil to plant a new Prosecco vineyard [74]. It is beyond the scope of this article to mention the wide array of further articles focusing on these stressful environmental conflicts and social disagreements, although the argument even found exposure in the worldwide tabloid The Sun [75].

Today the local consciousness regarding the quest for sustainability involves wine tourist perceptions as well. They are showing an increasing interest in the fascinating visual quality of the Prosecco landscape for wine tasting and purchasing and for other outdoor pursuits. The close relationship between wine tourists and Prosecco's scenic features, which were inherited from the past agrarian civilization, is well known. A bimonthly magazine (edited by the Consorzio di Tutela Prosecco Superiore) summarises the most popular iconographies of Prosecco's hillside vineyards [76]. In this context, it is worth noting that even local stakeholders have begun to pay attention to the perceptions of tourists: 'it is therefore important to create opportunities that will allow the consumer to admire ... the beauty of the landscape, so that state of mind, sensations and pleasant memories will become the connecting thread back to the locus and its wine' [4] (p. 245).

Visitors arrivals and the worldwide resonance of the environmental risks affecting this charming landscape are now compelling local and regional administrators to effectually adopt the detailed European and national directives concerning the proper management of agricultural pollutants. An encouraging alternative in winegrowing goes beyond development; some vintners are switching their conventional production to biological subsidised crops. This stimulating challenge express an enhancing trend among Italian winegrowers to the extent that Italy is the second largest organic wine producer in Europe [77]. In the specific case of Prosecco, the cellars that follow organic procedures such as ISO 14001 (environmental management) make up only 3\% of the total number of cellars. It is the most common eco-certification in the area, but there also other sustainability protocols and certifications that have attracted many cellars. These include Biodiversity Friend (promoted by the World Biodiversity Association), ISO 14067 (carbon footprint), ISO 50001 (Energy Management System), EMAS (Eco-Management and Audit Scheme), EPD-DAP (Environmental Product Declaration). The proportion of wine growers who have adopted these eco-sustainable procedures has increased from $5.3 \%$ in 2012 to $12.4 \%$ in 2016 [61].

Regarding sustainable and slow tourism, we can mention some innovative initiatives. The Solidarity Grape Harvest, located in San Pietro di Feletto, is promoted by the cellar Le Manzane. In 2017, this event attracted more than 450 participants, many of whom came from abroad, such as the Japanese importers who learned about the initiative and wanted to take part in the harvest. The Solidarity Grape Harvest is open to the public, and the proceeds are donated to charity. Another case is the Osteria senz'Oste (the Inn without an Innkeeper), which is located along the Conegliano Valdobbiadene Prosecco and Wines Road in the tiny village of Santo Stefano di 
Valdobbiadene. Its purpose is to offer a space where tourists and visitors can enjoy a traditional rural atmosphere in a rustic house and taste local products such as cheese, sopressa (a special local salami), bread, ham, eggs, traditional cakes and wine like Valdobbiadene prosecco, Docg or Cartizze. The style of payment makes this place unique; there is no cashier to ring up the bill. The customer has to judge the cost according to the quantity of food they consumed. These examples show sustainable development not only at productive and economic levels but also at the social and cultural ones.

\section{Conclusions: Arcadian Legacies and the Charm of Wine Tourism}

Despite the aforementioned environmental impacts, the morphological complexity of the Prosecco hillsides has prevented the intensive viticulture from spreading its dull and monotonous features. Different visual elements harmoniously arrange within a scenery of undisputable attractiveness. Landscape enchantment is thereby related to environmental diversification with a good deal of biodiversity, allowing specific ecosystem services capable of controlling pests [78]. Before the recent growth of wine and rural tourism, these rolling slopes were a well-known destination for cultural tourism due to the remarkable traces of artistic and historical heritage. Abbeys, castles, frescoed churches and Venetian age villas are the prestigious highlights that have attracted visitors since the beginning of the twentieth century [79].

Not unlike other hilly landscapes in the Venice inland, a sound bucolic tradition reinforced during the Renaissance covered the hillsides with aristocratic villas. The practicality of agrarian investments soon met the fascination of the pastoral myth and Andrea Palladio codified a charming residential aesthetic, of which villa Barbaro at Maser, just few miles from the core of the Prosecco landscape, may be considered to be his masterpiece [80]. Such Arcadian legacy was largely enhanced during Fascism when the rhetoric of rural idyll developed. At that time the idea of 'rural' expressed a pivotal strategy to claim more effectual social control, especially when considering the increasing risk of depopulation of the countryside. As clearly pointed out by Michael Woods [81] (p. 21), 'representations of the rural idyll were particularly popularized during the late nineteenth and early twentieth century, as Europe and North America became increasingly urbanized and industrialized. The rural idyll fed on discourses of anti-urbanism, agrarianism and nature that were used to differentiate between the urban present and a romanticized rural past'.

A substantial cultural redefinition of the Prosecco area as a new rural idyll occurred after the institution of the 'White Wine Road' in 1966, a sinuous and charming route wandering through the rolling slopes between Valdobbiadene and Conegliano [82]. This itinerary was the first Italian wine route and was undoubtedly a successful milestone in the national start of wine tourism [83]. It actually worked as an effective gate for the rediscovery of both cultural landscapes and the peculiar wine production and increased the habit of visiting local wineries among regional and national travellers. The increase of arrivals has been progressively encouraging a remarkable expansion of agritourist accommodations. In 2003, the White Wine Road was renamed as the 'Conegliano Valdobbiadene Prosecco and Wines Road', and the former route is now the main track of an integrated network of specific itineraries. Each itinerary allows tourists to discover the multifaceted landscape features of the Prosecco area, encouraging knowledge and appreciation of cultural heritage. The choice to expand the former itinerary attempts to fulfil the expectations of a broader range of visitors and foster the undisputable attractiveness of rural landscapes with its remarkable historical and artistic heritage. While a good number of guidebooks have recently been published, an overwhelming number of web pages are now easily available with more detailed suggestions of further itineraries, most of them devoted to hikers and cyclists. It follows that the previous predominance of wine tourists is now split into a specific segmentation of visitors, whose interests range from wine tasting to local gastronomy and from outdoor activities to historical heritage [84].

The Prosecco hills have now become an undisputable scenery for neo-Arcadian practices, deeply influencing large sections of popular culture. The noticeable closeness with the fringes of local urban sprawl reinforces the images of these rolling slopes as a kind of countryside ideal. Both insiders' 
and visitors' perceptions have transfigured a productive terraced winegrowing landscape into a rural idyll, therefore creating a territoriality of transition between urban and rural. The aspirations for a better quality environment increasingly associate counter-urbanization with the myth of a countryside where the harmonious coexistence among organic farming, leisure activities and finally the cultural growth provided by sustainable tourism and farm tourism facilities is possible [85]. As for the Prosecco area, the number of organic wine consumers are actually increasing due to the documented relationship between the attractiveness of rural landscape and the organoleptic quality of the wine sipped within this landscape [4] (p. 241). Today there is no doubt about the growing interest in organic wine, but according to the figures, 2016 sales of organic sparkling wine represented only the $0.6 \%$ of the entire production value ( 2.74 million out of a total of 492.5 million $€$ ), corresponding to the tiny $0.47 \%$ of the total estimated volume of bottles (429,000 bottles out of 90.4 million) [58,61].

Despite the poor economic prominence of organic viticulture, it entails intriguing symbolic values, addressing both conventional consumers and winegrowers towards the fascinating alternative of more sustainable behaviours. This 'green' vision is the push factor in the collaborative process involving both producers and consumers, therefore helping to preserve the landscapes' qualities and support investments in sustainable practices, which has been noted in several studies in a number of areas where the wine industry improved the sustainability of its practice [86-88].

According to the last report of the Consorzio Conegliano-Valdobbiadene, growing attention to the rural landscape came directly from the producers, if 'more than $60 \%$ of the sparkling wine companies have made, in 2016, interventions for the recovery and the enhancement of agrarian features and elements for conserving and enriching the environmental-heritage and the landscape [ ... ] to which it is accompanied a significant growth of expectations with respect to the recognition of the territory Conegliano Valdobbiadene as a UNESCO World Heritage Site' [61] (p. 8). Going further into this issue, this remark seems to have little more than rhetorical value considering the actual trend in the abovementioned UNESCO core zone, which is estimated at 20,300 hectares. This space is constantly under pressure due to the increasing value of the land and the continuously soaring price of grapes and wine. It follows that Prosecco producers are showing no ecological awareness, aiming at the dilatation of vineyards as much as possible. Indeed, as already noted, the increase of vineyards in the core area grew from 6578 hectares in 2013 to 7549 hectares in 2016. That is a growing percentage of about $5 \%$ with respect to the total amount of land considered by the UNESCO candidacy. This is a risk for such a complex and layered historical landscape because standardized and intensive cropping systems today represent a paramount issue in terms of environmental impact, since agricultural pollutants can constitute a potential threat to surface water, non-target organisms and aquatic ecosystems.

In relation to these changes, the task of the governance, in collaboration with local stakeholders and tourists, should embrace the whole of spatial dynamics, to generate adequate policies also taking into consideration external voices e.g., non-farmers, non-humans and grassroots movements, because there is 'a need to make wineries more cognisant of the community' [89] (p. 231). This mutual collaboration is very important because 'there needs to be a continued close relationship between the wine producers and their community to maximise potential and minimise any negative impacts' [90] (p. 301).The challenge of more sustainable approaches should start from a more local dimension, trying to recover the multiple issues recognizable within the ecological characters supporting the uniqueness of the Prosecco landscape, finally fostering a harmonious coexistence with the strength of economic driving forces as suggested in the very recent agreement among local administrators operating in the area. There are three important initiatives that could result in the more sustainable management of the landscape through spreading awareness of environmental issues among the local communities, stakeholders and policymakers. These planning and management initiatives started with the intention to improve territorial synergies (with varying successes). The first initiative is managed under an agreement between the 15 municipalities (part of the DOCG) and the Veneto Region. This agreement is presented in the Regolamento Comunale di Polizia Rurale [91] with all the necessary notations. Its aim is to improve the quality of the landscape. In particular, Article 11 
regulates the use of pesticides, not only strictly limiting their use but also improving the modality of their employment.

The second initiative is the promotion of a 'wine-growing protocol' (Protocollo vitivinicolo del Conegliano-Valdobbiadene Prosecco DOCG) that was set up by the Consorzio Conegliano Valdobbiadene [92]. The protocol is a document prepared by a special commission within the Consortium for fostering more effective and sustainable practices of plant protection and monitoring these practices. In particular, it pays attention to agronomic practices for the prevention and elimination of pests and weeds.

The last initiative established annual landscape courses that are promoted and organised by the Regional Landscape Observatory in collaboration with the regional universities. The Regional Landscape Observatory, launched in the context of the European Landscape Convention [93], is a board consisting of members of local administrations, universities, and the professional sector, as well as all social players, and it aims to achieve adequate territorial governance [94]. The Landscape Observatory's main goal is to develop and share among local stakeholders and policymakers a new awareness about landscape protection, management and planning strategies $[95,96]$. The Prosecco DOCG area was recently involved in a similar educational initiative that focused on improving the sustainability of its landscape management practices and protecting its cultural heritage. Wine tourism has allowed the Conegliano and Valdobbiadene areas to expand their tourism offerings, cross-promote other non-wine tourism offerings and create jobs; however, there is substantial room for improvement, especially regarding sustainability actions, the conservation of the traditional landscape and the reduction of its environmental impact.

Author Contributions: Francesco Visentin and Francesco Vallerani conceived and designed the research; Francesco Visentin and Francesco Vallerani wrote the manuscript and reviewed the results of the case study.

Conflicts of Interest: The authors declare no conflict of interest.

\section{References}

1. Cosgrove, D. Cultural Geography. In The Dictionary of Human Geography, 3rd ed.; Johnston, R.J., Gregory, D., Smith, D.M., Eds.; Basil Blackwell: Oxford, UK, 1994; p. 111.

2. Soule, D. (Ed.) Urban Sprawl: A Comprehensive Reference Guide; Greenwood Press: Westport, CT, USA, 2006.

3. OVSE. (Italian Economic Bubble Wine Observatory) 2014 Spumante Wines: Export Wins Hands Down. More Spumante than Champagne Bottles Sold in the World. Available online: http:/ /www.ovse.org/ homepage.cfm?idContent=181 (accessed on 4 April 2018).

4. Tomasi, D.; Gaiotti, F.; Jones, G. The Power of the Terroir: The Case Study of the Prosecco Wine; Springer: Basel, Switzerland, 2013.

5. UNESCO. Vineyard Landscape of Piedmont: Langhe-Roero and Monferrato. Available online: https://whc. unesco.org/en/list/1390 (accessed on 29 March 2018).

6. UNESCO. The Prosecco Hills of Conegliano and Valdobbiadene. Tentative List. Available online: http:/ /whc. unesco.org/en/tentativelists/5566/ (accessed on 29 March 2018).

7. Graham, B.; Howard, P. (Eds.) Heritage and Identity; Ashgate: Farnham, UK, 2008.

8. Cosgrove, D. The Palladian Landscape; Leicester University Press: London, UK, 1993.

9. Colombo, F. Prosecco Perché? Le Nobili Origini di un Vino Triestino; Luglio Editore: Trieste, Italy, 2012.

10. Balbi Valier, M.G. Per le Auspicatissime Nozze Bianchini-Dubois, in Segno di Affettuosa Amicizia e stima [ ... ] Lettera Sulle Coltivazioni di Pieve di Soligo; Longo: Treviso, Italy, 1868.

11. Rorato, G. Il Prosecco di Conegliano-Valdobbiadene; Morganti: Verona, Italy, 2006.

12. Tomasi, D.; Dalle Ceste, M.; Tempesta, T. (Eds.) I Paesaggi Vitati del Conegliano Valdobbiadene, Delle Pianure del Piave e del Livenza: Evoluzione e Legame con la Qualità del Vino; CRA-VIT: Treviso, Italy, 2014.

13. Whetzel, H.H. An Outline of the History of Phytopathology; W. B. Saunders: Philadelphia, PA, USA, 1918.

14. Dalmasso, G. Vini Bianchi Tipici dei Colli Trevigiani: Sottozone di Conegliano e Valdobbiadene; Longo e Zoppelli, Stazione Sperimentale di Viticoltura e Enologia: Treviso, Italy, 1937.

15. Vianello, A.; Carpenè, A. La Vite e il Vino in Provincia di Treviso; Loescher: Torino, Italy, 1874. 
16. Jacini, S. I Risultati Della Inchiesta Agraria. Relazione Pubblicata Negli Atti Della Giunta per la Inchiesta Agraria; Einaudi: Torino, Italy, 1976.

17. Cosgrove, D. From Palladian Landscape to the Città Diffusa: the Veneto and Los Angeles. In European Landscapes and Lifestyles. The Mediterranean and Beyond; Roca, Z., Spek, T., Terkenli, T., Eds.; Edicôes Universitàrias Lusòfonas: Lisboa, Portugal, 2007; pp. 33-44.

18. United Nations World Tourism Organization. 2018. Available online: http://www2.unwto.org/ (accessed on 10 April 2018).

19. Osservatorio Nazionale del Turismo-Data 2017. Available online: http://www.ontit.it/opencms/opencms / ont/it/stampa/in_evidenza/il_belpaese_chiude_il_2017_con_delle_presenze (accessed on 17 April 2018).

20. Osservatorio Nazionale del Turismo, 2018. Statistics. Available online: http://www.ontit.it/opencms / opencms/ont/it/statistiche/index.html (accessed on 10 April 2018).

21. ISTAT. 2018. Available online: https:/ / www.istat.it/ (accessed on 10 April 2018).

22. Direzione Sistema Statistico Regione Veneto, Turismo 2018. Available online: http:/ / statistica.regione.veneto. it/banche_dati_economia_turismo.jsp (accessed on 10 April 2018).

23. UNWTO. Compendium of Tourism Statistics Glossary. Available online: http://cf.cdn.unwto.org/sites/all/ files/pdf/methodological_notes_2018.pdf (accessed on 29 May 2018).

24. Manente, M. Economia turistica regionale nel 2010. In Proceedings of the Atti dell'XI Conferenza Ciset, Venezia, Italy, 19 April 2011; Banca d'Italia: Venezia, Italy, 2011.

25. Manente, M. Oral presentation: Economia turistica regionale nel 2012. In Proceedings of the L'Italia e il Turismo Internazionale: Andamento Incoming e Outgoing nel 2012, Conference: CISET and Banca d'Italia, Venezia, Italy, 17 April 2013.

26. Golja, T.; Krstinic Nizic, M. Corporate social responsibility in tourism-The most popular tourism destinations in Croatia: Comparative analysis. Manag. J. Contempor. Manag. Issues 2010, 15, 107-121.

27. Del Chiappa, G.; Grappi, S.; Romani, S. Attitudes toward responsible tourism and behavioral change to practice it: A demand-side perspective in the context of Italy. J. Qual. Assur. Hosp. Tour. 2016, 17, 191-208. [CrossRef]

28. Regione Veneto Sistema Statistico Regionale 2015. Available online: http://statistica.regione.veneto.it/ banche_dati_economia_turismo.jsp (accessed on 1 April 2018).

29. Santeramo, F.B.; Seccia, A.; Nardone, G. The synergies of the Italian wine and tourism sectors. Wine Econ. Policy 2016, 6, 71-74. [CrossRef]

30. Croce, E.; Perri, G. Food and Wine Tourism. Integrating Food, Travel and Terroir; CABI: Wallingford, UK, 2017.

31. Charters, S.; Ali-Knight, J. Who is the wine tourists? Tour. Manag. 2002, 23, 311-319. [CrossRef]

32. Getz, D.; Brown, G. Critical success factors for wine tourism regions: A demand analysis. Tour. Manag. 2006, 27, 146-158. [CrossRef]

33. Hall, C.M.; Sharples, L.; Cambourne, B.; Macionis, N. Wine Tourism around the World; Butterworth-Heinemann: Oxford, UK, 2000.

34. Hall, C.M.; Mitchell, R. Wine tourism in the Mediterranean: A tool for restructuring and development. Thunderbird Int. Bus. Rev. 2000, 42, 445-465. [CrossRef]

35. Boniface, P. Tasting Tourism: Travelling for Food and Drink; Ashgate: Burlington, UK, 2003.

36. Hall, C.M. Wine, Food and Tourism Marketing; The Haworth Hospitality Press: Binghamton, NY, USA, 2013.

37. Kim, Y.G.; Eves, A.; Scarles, C. Building a model of local food consumption on trips and holidays: A grounded theory approach. Int. J. Hosp. Manag. 2009, 28, 423-431. [CrossRef]

38. Miles, S. The Western Front: Landscape, Tourism, and Heritage; Pen and Sword Books: Barnsley, UK, 2017.

39. Terkenli, T.S. Landscape of Tourism: Towards a Global Cultural Economy of Space. Tour. Geogr. 2005, 4, $227-254$. [CrossRef]

40. O'Hare, D. Interpreting the Cultural Landscape for Tourism Development. Urban Des. Int. 1997, 2, 33-54. [CrossRef]

41. Knudsen, D.C.; Michelle, M.; Metro-Roland, A.; Soper, K.; Greer, C.E. (Eds.) Landscape, Tourism, and Meaning; Ashgate Publishing: Burlington, VT, USA; Aldershot, UK, 2008.

42. Daugstad, K. Negotiating landscape in rural tourism. Ann. Tour. Res. 2008, 35, 402-426. [CrossRef]

43. Lane, B. What is Rural Tourism? J. Sustain. Tour. 1994, 2, 7-22. [CrossRef]

44. Sznajder, M.; Przezbòrska, L.; Scrimgeour, F. Agritourism; CABI: Wallingford, UK, 2009. 
45. Thompson, M.; Prideaux, B.; McShane, C.; Dale, A.; Turnour, J.; Atkinson, M. Tourism development in agricultural landscapes: The case of the Atherton Tablelands, Australia. Landsc. Res. 2016, 41, 730-743. [CrossRef]

46. Briedenhann, J.; Wickens, E. Rural Tourism-Meeting the challenges of the New South Africa. Int. J. Tour. Res. 2004, 6, 189-203. [CrossRef]

47. Gülcan, Y.; Kuştepeli, Y.; Akgüngör, S. Public Policies and Development of the Tourism Industry in the Aegean Region. Eur. Plan. Stud. 2009, 17, 1509-1523. [CrossRef]

48. Lane, B. Rural Tourism: An Overview. In The Sage Handbook of Tourist Studies; Jamal, T., Robinson, M., Eds.; SAGE: London, UK, 2009; pp. 354-371.

49. Dimitrovski, D.; Todorovic, A.; Valjarevic, A. Rural Tourism and Regional Development: Case Study of Development of Rural Tourism in the Region of Gruţa, Serbia. Procedia Environ. Sci. 2012, 14, $288-297$. [CrossRef]

50. Dashper, K. Rural Tourism: An International Perspective; Cambridge Scholars Publishing: Newcastle, UK, 2014.

51. Miller, E.; van Megen, K.; Buys, L. Impact and opportunities: Residents' views on sustainable development tourism in regional Queensland, Australia. J. Tour. Chall. Trends 2010, 31, 175-194.

52. Tempesta, T.; Giancristofaro, R.; Corain, L.; Salmaso, L.; Tomasi, D.; Boatto, V. The importance of landscape in wine quality perception: An integrated approach using choice-based conjoint analysis and combination-based permutation tests. Food Qual. Perform. 2010, 21, 827-836. [CrossRef]

53. Meneghello, S.; Manente, M. Dinamiche del Turismo in Provincia di Treviso. Focus Sulla Fruizione Enologica Nel Distretto Conegliano-Valdobbiadene; CIRVE: Padua, Italy, 2012; pp. 161-182.

54. Mauracher, C.; Procidano, I.; Sacchi, G. Wine tourism quality perception and customer satisfaction reliability: The Italian Prosecco District. J. Wine Res. 2016, 27, 284-299. [CrossRef]

55. Boatto, V.; Galletto, L.; Barisan, L.; Bianchin, F. The development of wine tourism in the Conegliano Valdobbiadene area. Wine Econ. Policy 2013, 2, 93-101. [CrossRef]

56. Tempesta, T.; Vecchiato, D.; Djumboung, D.A.; Chinazzi, G. An analysis of the potential effects of the modification of the Prosecco Protected Designation of Origin: A choice experiment. Int. Agric. Policy 2013, 2, 33-47.

57. Manente, M.; Meneghello, S.; Mingotto, E. Dinamiche del turismo nel Distretto Conegliano-Valdobbiadene. Focus sulla fruizione enologica. In Distretto del Conegliano-Valdobbiadene. Rapporto Annuale 2017; CIRVE: Padua, Italy, 2017. Available online: http:/ / www.prosecco.it/wp-content/uploads/2015/06/coneglianovaldobbiadene_ rapporto-economico-2017.pdf (accessed on 5 April 2018).

58. Annual Report of the Consorzio of Conegliano-Valdobbiadene 2014. Available online: http:/ /www.prosecco. it/wp-content/uploads/2015/06/report_2014.pdf (accessed on 3 May 2018).

59. Annual Report of the Consorzio of Conegliano-Valdobbiadene 2015. Available online: http:/ / www.prosecco. it/wp-content/uploads /2015/06/2015-rapporto-4A.pdf (accessed on 3 May 2018).

60. Annual Report of the Consorzio of Conegliano-Valdobbiadene 2016. Available online: http:/ /www.prosecco.it/ wp-content/uploads/2015/06/2016rapporto_annualeConeglianoValdobbiadene.pdf (accessed on 4 May 2018).

61. Annual Report of the Consorzio of Conegliano-Valdobbiadene 2017. Available online: http:/ / www.prosecco. it/wp-content/uploads/2015/06/coneglianovaldobbiadene_rapporto-economico-2017.pdf (accessed on 4 May 2018).

62. CIRVE. 2016. Available online: http://www.cirve.unipd.it/it/index.html (accessed on 10 May 2018).

63. Bourdeau, L.; Gravari-Barbas, M.; Robinson, M. (Eds.) World Heritage Sites and Tourism. Global and Local Relations; Routledge: London, UK, 2017; pp. 1-17.

64. Vallerani, F. Urban sprawl on the Venice mainland: Risks for the regional public heritage. Revista Movimentos Sociais e Dinâmicas Espaciais. 2012, 1, 130-147.

65. La Tribuna di Treviso. Troppi Sbancamenti Sui Colli del Prosecco. 2018. Available online: http:/ / tribunatreviso.gelocal.it/treviso/cronaca/2018/04/10/news/troppi-sbancamenti-sui-colli-del-proseccosos-dalla-marcia-stop-pesticidi-1.16695788 (accessed on 4 May 2018).

66. La Tribuna di Treviso. Bosco Venduto e Abbattuto. $<$ E ora pure avvelenato $>$. 2013. Available online: http:/ / ricerca.gelocal.it/tribunatreviso/archivio/tribunatreviso/2013/05/11/NZ_39_01.html (accessed on 4 May 2018). 
67. De Nardi, C. Poisoned Prosecco Vineyards and the Downside of an Italian Icon: Analyses of Pesticides' Impact on the Environment and Human Health. 2016. Available online: https:/ / www.google.com/url?sa=t\&rct=j\&q=\&esrc= s\&source=web\&cd=1\&cad=rja\&uact=8\&ved=0ahUKEwjHo6O2vu7bAhWC7mEKHUmCBaoQFgglMAA\& url=https $\% 3 \mathrm{~A} \% 2 \mathrm{~F} \% 2 \mathrm{Fandiamoavantitornandoindietro.jimdo.com} \% 2 \mathrm{Fapp} \% 2 \mathrm{Fdownload} \% 2 \mathrm{~F} 10826016695 \%$ 2FTesi\%2BDe\%2BNardi\%2BCamilla\%2B-\%2BFinal\%2BThesis\%2BProject.pdf\%3Ft\%3D1482486345\&usg= AOvVaw0mwfuWY1r-JuE6p_CxIwbl (accessed on 26 April 2018).

68. The Telegraph. Wine War in Tuscany as Growers Warned that Vines Damage Environment. Available online: https://www.telegraph.co.uk/news/worldnews/europe/italy/11070631/Wine-war-in-Tuscanyas-growers-warned-that-vines-damage-environment.html (accessed on 28 April 2018).

69. Löffler, R.; Walder, J.; Beismann, M.; Warmuth, W.; Steinicke, E. Amenity Migration in the Alps: Applying Models of Motivations and Effects to 2 Case Studies in Italy. Mt. Res. Dev. 2016, 36, 484-493. [CrossRef]

70. La Tribuna di Treviso. Boschi Rasi al Suolo per il Prosecco Docg. Scoppia la Protesta. 2012. Available online: http: / / tribunatreviso.gelocal.it/treviso/cronaca/2012/05/01/news/boschi-rasi-al-suolo-per-ilprosecco-docg-scoppia-la-protesta-1.4449701 (accessed on 26 April 2018).

71. Gliessman, S. Agroecology. The Ecology of Sustainable Food Systems; CRC Press: Boca Raton, FL, USA, 2007.

72. Pizzaro, P.; Ferrarese, F.; Loddo, D.; Pappalardo, E.; Varotto, M. Mapping the Environmental Risk Potential on Surface Water of Pesticide Contamination in the Prosecco's Vineyard Terraced Landscape. Presented at the European Geosciences Union General Assembly 2016, Vienna, Austria, 17-22 April 2016.

73. European Community. Directive on the Use of Sustainable Pesticides. 2009. Available online: http:/ / eurlex.europa.eu/legal-content/EN/TXT/PDF/?uri=CELEX:02009L0128-20091125\&from=EN (accessed on 26 April 2018).

74. Corriere del Veneto. Prosecco, Guerra Sui Limiti Anti-Pesticidi. 2017. Available online: http:/ / corrieredelveneto.corriere.it/treviso/cronaca/17_dicembre_17/via-limiti-coltivazione-vignetiscattaricorso-tar-guerra-prosecco-7fb7a178-e3e6-11e7-a729-a41e0748ec41.shtml (accessed on 26 April 2018).

75. The Sun. Prosecco in Bubble Trouble. Production of Brits' Favourite Fizz Leaves Italian Villagers with Cancer after being Exposed to Dangerous Chemicals. 2016. Available online: https:/ /www.thesun.co.uk/news/2267601/ production-of-brits-favourite-fizz-prosecco-is-leaving-italians-with-with-cancer-and-exposed-to-dangerouschemicals / (accessed on 4 May 2018).

76. Visit Conegliano Valdobbiadene. Available online: http://www.prosecco.it/it/territorio/visit-coneglianovaldobbiadene/ (accessed on 12 April 2018).

77. NOMISMA. Vino Bio: Nel 2015 in Crescita il Numero di Consumatori Italiani. 2015. Available online: http:/ / www.nomisma.it/index.php/it/press-area/comunicati-stampa/item/823-20-marzo-2015-vinobio-nel-2015-in-crescita-il-numero-di-consumatori-italiani/823-20-marzo-2015-vino-bio-nel-2015-increscita-il-numero-di-consumatori-italiani (accessed on 4 May 2018).

78. Storck, V.; Karpouzas, D.G.; Martin-Laurent, F. Towards a better pesticide policy for the European Union. Sci. Total Environ. 2017, 575, 1027-1033. [CrossRef] [PubMed]

79. Baedeker, K. Italie Septentrionale. Manuel du Voyageur; Baedeker: Leipzig, Germany, 1908.

80. Palladio, A. I Quattro Libri dell'Architettura; Franceschi: Venetia, Italy, 1570.

81. Woods, M. Rural; Routledge: Abingdon, UK, 2011.

82. Schiratti, G. Invito Alla Strada del Vino Bianco: Conegliano-Valdobbiadene; Editrice Trevigiana: Treviso, Italy, 1972.

83. Sanson, L. La vite in collina. In Valdobbiadene fra Tradizione E Innovazione; Cierre Edizioni: Verona, Italy, 2002.

84. Bitsani, E.; Kavoura, A. Connecting oenological and gastronomical tourisms at the Wine Roads, Veneto, Italy, for the promotion and development of agritourism. J. Vacat. Mark. 2012, 18, 301-312. [CrossRef]

85. Borghesi, R. Reinventare la campagna, a cominciare dal paesaggio. In Per una Nuova Urbanità. Dopo L'alluvione Immobiliarista; Bonora, P., Cervellati, P., Eds.; Diabasis: Reggio Emilia, Italy, 2009; pp. 190-213.

86. Marshall, R.S.; Cordano, M.; Silverman, M. Exploring individual and institutional drivers of proactive environmentalism in the US wine industry. Bus. Strategy Environ. 2005, 14, 92-109. [CrossRef]

87. Marshall, R.S.; Akoorie, M.E.M.; Hamann, R.; Sinha, P. Environmental practices in the wine industry: An empirical application of the theory of reasoned action and stakeholder theory in the United States and New Zealand. J. World Bus. 2010, 45, 405-414. [CrossRef]

88. Christ, K.L.; Burritt, R.L. Critical environmental concerns in wine production: An integrative review. J. Clean. Prod. 2013, 53, 232-242. [CrossRef]

89. Holmes, M.R. Integrated rural wine tourism: A case study approach. J. Wine Res. 2017, 28, 216-238. [CrossRef] 
90. Sheridan, L.; Alonso, A.D.; Scherrer, P. Wine tourism as a development initiative in rural Canary Island communities. J. Enterp. Communities People Places Glob. Econ. 2009, 3, 291-305. [CrossRef]

91. Regolamento Comunale di Polizia Rurale 2018. Available online: http:/ / www.cittadelvino.it/download. php?file=regolamento-intercomunale-di-polizia-rurale-prosecco_25.pdf. (accessed on 30 May 2018).

92. Wine-Growing Protocol. Protocollo Vitivinicolo del Conegliano-Valdobbiadene Prosecco DOCG. 2018. Available online: http:/ / www.prosecco.it/wp-content/uploads/2018/04/Protocollo-2018-Pagine-Web.pdf (accessed on 31 May 2018).

93. Council of Europe. European Landscape Convention. CETS No. 176. 2000. Available online: https: / /rm.coe.int/1680080621 (accessed on 31 May 2018).

94. Nogué, J. El Observatorio del Paisaje de Catalunya. Rev. Geogr. Venez. 2010, 103-121.

95. Visentin, F. Gli osservatori del paesaggio tra istituzionalizzazione e azione dal basso. Esperienze regionali a confronto. Bollettino della Società Geografica Italiana 2012, 5, 823-838.

96. Visentin, F. Area dynamics and social participation: From the European Landscape Convention to the Observatori del Paisatge de Catalunya. Revista Movimentos Sociais e Dinamicas Espaciais 2013, 2, 54-73.

(C) 2018 by the authors. Licensee MDPI, Basel, Switzerland. This article is an open access article distributed under the terms and conditions of the Creative Commons Attribution (CC BY) license (http:/ / creativecommons.org/licenses/by/4.0/). 